\title{
International College of Psychosomatic Medicine
}

\author{
Tom Sensky \\ President International College of Psychosomatic Medicine, Isleworth, UK
}

Giovanni Fava's editorial in this issue of Psychotherapy and Psychosomatics offers a timely reminder of the principal aims of psychosomatic medicine and, equally important, some of its key values. These aims and values reflect those of the journal, and of course also those of the International College of Psychosomatic Medicine. This is one reason why the International College is proud of its association with Psychotherapy and Psychosomatics, and also with the Journal of Psychosomatic Research.

The International College is still celebrating the success of the 18th World Congress on Psychosomatic Medicine, held in Kobe, Japan, at the end of August 2005. At the opening ceremony, we were honoured by the presence of their Imperial Highnesses the Emperor and Empress of Japan. More than a thousand delegates from over thirty countries participated in the Congress. One particularly striking theme was the juxtaposition of oriental and occidental traditions of practice and inquiry. On behalf of the International College, I wish to thank all those who contributed to the success of the Congress, and particularly the co-chairs of the organizing committee, Professors Tomifusa Kuboki and Chiharu Kubo.

The Kobe Congress built on the success of the 2001 Congress in Gothenburg and the 2003 Congress in Hawaii. We are very confident that the 19th World Congress will also be a great success. It will be held at the Quebec City Convention Center, Quebec City, Canada, on 26-31 August 2007. Please visit the Congress's web page (www.icpm2007.ca) to keep up with the Congress as it develops, and to register. The co-chairs of the organising committee are Professors Fabien Gagnon and Louis van Zyl. Fabien Gagnon is Chair of the Department of Psychiatry at Laval University, and Chief of the Consultation-Liaison and Psychosomatic Service at the Centre Hospitalier Universitaire de Québec. Louis van Zyl is Head of the Division of Psychosomatic Medicine at Queens University, Kingston, Ontario.

Sponsorship of the World Congress is only one of the activities of the International College. Members and Fellows of the Interna- tional College enjoy the substantial benefit of receiving Psychotherapy and Psychosomatics and Journal of Psychosomatic Medicine as part of their annual subscription to the College. Fellowship of the International College confers international peer recognition for research and/or other work in psychosomatic medicine. The College will run specialist workshops at the World Congresses and elsewhere, to which College members will have priority access, and for which non-College members will need to pay a fee. The College is expanding its website, with plans to make available to members only, in a password-protected part of the website, a variety of useful resources in psychosomatic medicine, including information about recent publications by College members, and material from lectures and workshops that members are willing to share with their colleagues.

The current Executive Board of the International College comprises Tom Sensky (UK, President), George Christodoulou (Greece, Past President), Jon Streltzer (USA, Secretary), Chiharu Kubo (Japan, Treasurer), Giovanni Fava (Italy, First President Elect) and Arnstein Finset (Norway, Second President Elect).

The International College is always keen to welcome new members - membership is open to people of any profession who have an interest in psychosomatic medicine. More information about membership, and an online membership application form, are available on the College's website - www.icpm.org. For further information, you are very welcome to contact the International College of Psychosomatic Medicine secretariat.

\section{Key Contacts \\ International College of Psychosomatic Medicine: www.icpm.org \\ International College of Psychosomatic Medicine \\ Secretariat e-mail: secretariat@icpm.org \\ 19th World Congress on Psychosomatic Medicine: www.icpm2007.ca}

\section{KARGER}

Fax +41613061234 E-Mail karger@karger.ch www.karger.com 